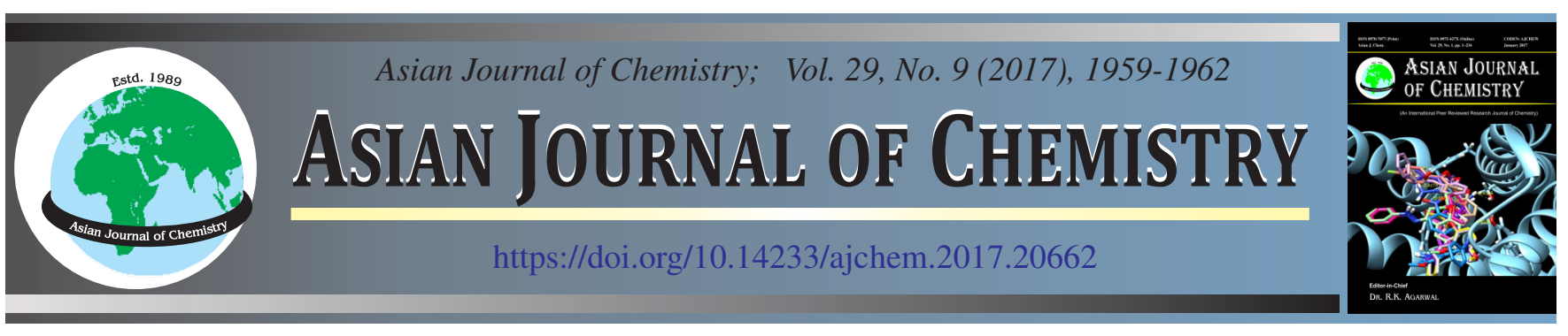

\title{
A Novel 4-(1H-Benzimidazol-2-yl)-2-methoxy-phenol Derived Fluorescent Sensor for Determination of $\mathrm{CN}^{-}$Ion
}

\author{
R. Rahmawati ${ }^{1,2,}$, B. Purwono² and S. MatsJeh ${ }^{2}$
}

${ }^{1}$ Study Program of Chemistry, Department of Education of Mathematics and Natural Sciences, Universitas Mataram, Jalan Majapahit 62, Mataram, Indonesia

${ }^{2}$ Department of Chemistry, Universitas Gadjah Mada, Jalan Kaliurang Sekip Utara, Bulaksumur 21, Yogyakarta, Indonesia

*Corresponding author: E-mail: mymine76@ymail.com

Received: 21 March 2017;

Accepted: 15 June 2017;

Published online: 15 July 2017;

AJC-18473

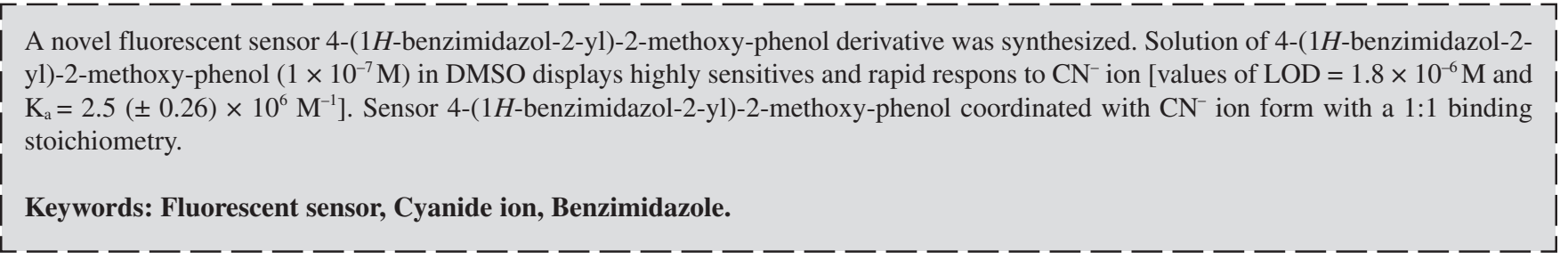

\section{INTRODUCTION}

Research on design and development of artificial molecular sensor for recognition and sensing of anion is currently attracting much interest because anion plays many fundamental roles in chemical and biological process [1]. In recent year, increasing attention in the field of host-guest chemistry has been devoted to the fast development of anion recognition system. The development of fluorescent and colorimetric probes for anion is finely and an area of interest. Water soluble anions (one of them is cyanide) play crucial roles in a range of biological phenomenan and are implicated in many disease states [2].

Cyanide is traditionally known as a poison and has been used in mass homicides and suicides and as a weapon of war. Sodium and potassium cyanide salts are widely used in many industries like extracting prosess for the recovery of gold and silver, electroplating, dyeing, printing and in the synthesis of organic and inorganic chemicals (nitriles, amides, esters and amines) as well as producting of chelating agents [3].

The cyanide anion $\left(\mathrm{CN}^{-}\right)$is known as one of the most rapidly acting and powerful poisons [4]. It is an extremely toxic anion and can directly lead to the death of human beings in several minutes. The cyanide ion also detrimentally affects vascular, visual, central nervous, cardiac, endocrine and metabolic functions. However, cyanide toxicity, large quantites of cyanide salt are still widely used in industrial production [5].
The investigation on synthesis of anion receptor have attracted a number of chemists due to the key roles played by anions during the chemicals, biological and environmental prosesses [6]. Fluorescence sensation is an exceptional technique among the different detection methods used for recognition of different anion, such as cyanide anion, because of its high sensitivity [7]. Consequently, cyanide selective detection and quantification are very important, which has been the object of increasing investigation [8].

The synthesis of sensory compound to detect $\mathrm{CN}^{-}$ion has been largely reported. The sensory compound of fluorescence for anion $\mathrm{CN}^{-}$through the formulation of complex between sensor and ion copper has been reported to have a high selectivity $\left(\mathrm{LOD}=1.4 \times 10^{-5} \mathrm{M}, \mathrm{K}_{\mathrm{s}}=3.3 \times 10^{3} \mathrm{M}^{-1}\right)$, the improvement of its fluorescence happened due to the presence of attractiveness of copper-cyanide [9]. 4-[(1E)-2-(4-hydroxyphenyl)ethenyl]-1allylpyridinium bromide (HPEAPB) compound is also used as colorimetry sensor to detect $\mathrm{CN}^{-}$ion, because this sensor has a high selectivity and fast response with LOD value equals $3.4 \times$ $10^{6} \mathrm{M}$ [10]. A compound diluted in DMSO/HEPES buffer was used to detect $\mathrm{CN}^{-}$ion, the $\mathrm{LOD}$ of $\mathrm{CN}^{-}$was measured through $\mathrm{UV}$-visible titration experiment, LOD value is $10.3 \mu \mathrm{M}$ [11].

Benzimidazole and its derivatives have been studied in anion and cation recognition system that display colour changes or fluorescence quenching or enhancement upon binding. The different substituents at the benzimidazole are intended to improve the intramolecular electron delocalization and will tune the photophysical properties of new sensors and optimize 
of the recognition of target analytes through a greater sensitivity of fluorescence [12]. Compound from benzimidazole group has been largely reported in terms of its roles as antioxidant [13] and chemosensor. Azo dye compound featuring with benzimidazole moiety has been used as chemosensor of ratiometric and colorimetric to detect $\mathrm{CN}^{-}$ion, this recognition produced $\mathrm{K}_{\text {binding }}$ value $=9.54 \times 10^{9} \mathrm{M}^{-1}$, the interactions of sensory-ion occured with the ratio of stoichiometry 1:2 [14]. Other compound having benzimidazole group, that has substituent of $\mathrm{OH}$ clusters, has also been used to detect $\mathrm{CN}^{-}$ ion in the protic/aqueous systems gives $\mathrm{K}_{\text {binding }}$ value $=0.45 \times$ $10^{3} \mathrm{M}^{-1}$ [15]. Triphenylimidazole compound (contains ring of benzimidazole) has also been used as colorometric and fluorescence sensor to detect $\mathrm{CN}^{-}$anion with the $\mathrm{LOD}$ value $=0.11$ $\times 10^{-6} \mathrm{M}$ [16]. A compound bearing 2-(2'-hydroxyphenyl) benzimidazole was investigated an a sensor for metal ions by using UV-visible and spectroscopy method [17]. Benzimidazole was using to designed a rapid "OFF-ON" fluorescent sensor system based on the selective response of in situ formed L-Fe ${ }^{3+}$ complexes toward $\mathrm{H}_{2} \mathrm{PO}_{4}^{-}[18]$.

The traditional synthesis of benzamidazole involves the reaction between $o$-phenylenediamine and carboxylic acid or their derivatives in the presence of strong acid such as polyphosphoric acid and presence of expensive catalysts (such as sulphur, $\mathrm{FeCl}_{3}, \mathrm{H}_{2} \mathrm{O}_{2}, \mathrm{HCl}, \mathrm{CAN}, \mathrm{NaN}_{3}, \mathrm{CuCl}$, oxone, $\mathrm{PhI}(\mathrm{OAc})_{2}, \mathrm{BH}_{3}$ and using alumina and zirconia) and precence of organic solvent (such as DMSO, DMF, toluene and dioxane) at elevated temperature [19-22].

In this work, the new fluorescence sensory compound from benzimidazole as receptor to detect $\mathrm{CN}^{-}$ion has been synthesized. The advantages of this receptor is its simple structure. It has the substituent of $\mathrm{OH}$ clusters from its vanillin skeletons used as a binding site that forms hydrogen bonds with $\mathrm{CN}^{-}$anion and has a high flourometric sensitivity to recognize $\mathrm{CN}^{-}$anion with a low detection limit value. The behaviour of this new compound towards $\mathrm{CN}^{-}$anion was investigated by fluorescence spectroscopy in DMSO.

\section{EXPERIMENTAL}

The predominance of this synthesis is use of inexpensive and sustainable catalyst, the use of non-organic solvents and its short reaction time. The use of vanillin as a source of carbonyl synthesis of benzimidzole derivatives have not been reported previously.

The synthesized compound has a character as a good chemosensor compound because it contains two auxochrome groups (such as two -OH and -OMe groups) and two systems of conjugations which strengthen the fluorescent properties.

Melting point was measured using a Electrothermal-9100, the functional group were detected using a FTIR Shimadzu Prestige-21, Mass spectra were taken by Gas ChromatographMass Spectrometer (GCMS-QP2010S), ${ }^{1} \mathrm{H}$ NMR and ${ }^{13} \mathrm{C}$ NMR were measured using a JOEL JNM ECA-500 MHz, fluorescent were measured using a Spectro Fluorophotometer Shimadzu RF-6000.

All the reagents for synthesis obtained commercially were used without further purification, e.g., DMSO, aquadest, ethanol. The material used in the synthesis are vanillin, $o$ phenylendiamine, boric acid. The anion were added in the form of sodium cyanide ( $\mathrm{NaCN}$ salt). All materials for synthesis is p.a. quality Merck.

The method on this synthesis is adopted from KarimiJaberi and Amiri method [6]. A vanillin (0.32 g), o-phenylendiamine $(0.21 \mathrm{~g})$ and boric acid $(0.1 \mathrm{~g})$, were diluted in $5 \mathrm{~mL}$ hot water. A mixture was stirred at $40^{\circ} \mathrm{C}$ for $5 \mathrm{~min}$ (the progress of reaction was monitored by TLC). After completion of reaction, the obtained solid was collected by filtration and purified by recrystallization from boiling ethanol (SchemeI). Light yellow powder, $94 \%$ yield (0.22 g), m.p 229-231 ${ }^{\circ} \mathrm{C}$; FTIR $\left(\mathrm{KBr}, \mathrm{v}_{\max }, \mathrm{cm}^{-1}\right): 3387 \mathrm{OH} \& \mathrm{~N}-\mathrm{H}, 2337.72 \mathrm{C}=\mathrm{N}$, 1604.77 C=C aromatic (3062.96 C-H $\left.s p^{2}\right), 2931 \mathrm{C}-\mathrm{H}$ methyl, $1273.02 \mathrm{C}-\mathrm{O}-\mathrm{C}) ;{ }^{1} \mathrm{H}$ NMR (500 MHz, $\mathrm{CDCl}_{3}: 3.59$ (m, 3H), $5.437(\mathrm{~m}, 1 \mathrm{H}), 6.372(\mathrm{~d}, 1 \mathrm{H}), 6.642(\mathrm{~s}, 1 \mathrm{H}), 6.692(\mathrm{~s}, 1 \mathrm{H})$, $7.24(\mathrm{~s}, 2 \mathrm{H}), 7.51(\mathrm{~s}, 1 \mathrm{H}), 7.664(\mathrm{~m}, 1 \mathrm{H}), 9.004(\mathrm{~d}, 1 \mathrm{H}), 9.586$ (s, $1 \mathrm{H}) ;{ }^{13} \mathrm{C}$ NMR $\left(500 \mathrm{MHz}, \mathrm{CDCl}_{3}: 55.49,110.69,112.99\right.$, 115.56, 118.54, 122.06, 127.89, 136.06, 142.6, 145.86, 147.7, 148.22, 153.59). MS (EI): $m / z, 240\left(\mathbf{M}^{+}, 100 \%\right), 137\left(\mathbf{M}^{+}, 80\right.$ $\%), 122\left(\mathrm{M}^{+}, 9 \%\right), 65\left(\mathrm{M}^{+}, 7 \%\right)$.

\section{RESULTS AND DISCUSSION}

The compound $\mathbf{S}_{\mathbf{1}}$ was used to detect the cyanide ion. The concentration of sensor used was $1 \times 10^{-7} \mathrm{M}$ and of anions used was $1 \times 10^{-6} \mathrm{M}$. In term of colour indicator, there was not any change, which means the colorimetry did not occur. In the observation under $366 \mathrm{~nm}$ UV light, it showed that the compound $\mathbf{S}_{\mathbf{1}}$ is fluorescent in nature (Fig. 1).

The $\mathrm{CN}^{-}$detection indicated activity of anions through hydrogen bond formation that occurs in the side of $-\mathrm{OH}$ binding site [23]. The selectivity of the host for a specific anion of interest could be rationalized on the basis of not only the guest basicity but also complementary shape between the host and the anionic guest. In particular, multiple hydrogen-bonding<smiles>COc1ccc(C=O)cc1O</smiles><smiles>Nc1ccccc1N</smiles>
Light brown $\underset{\text { Stirred } 40{ }^{\circ} \mathrm{C}}{\stackrel{0.1 \mathrm{~g} \text { Boric acid }}{\longrightarrow}}$ White

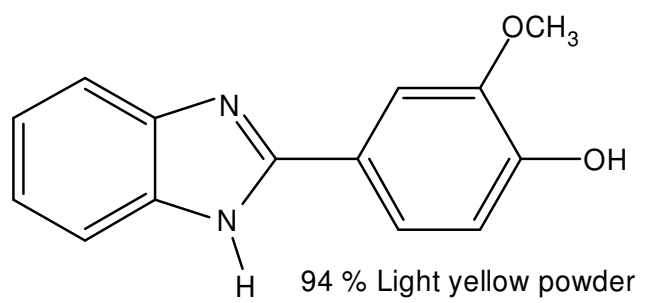

$\mathrm{S}_{1}$

Scheme-I: Synthesis of the sensor compound $\mathbf{S}_{\mathbf{1}}$ 

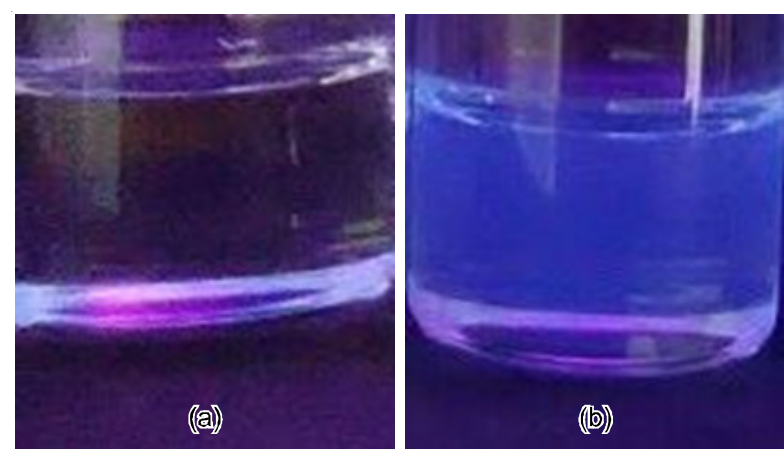

Fig. 1. Fluorescence view of $\mathbf{S}_{\mathbf{1}}\left[1 \times 10^{-7} \mathbf{M}\right]$ (a) and $\mathbf{S}_{\mathbf{1}}+\mathrm{CN}^{-}\left[5 \times 10^{-6} \mathbf{M}\right]$ (b) in DMSO under UV lamp

interactions were necessary in high-affinity anion binding sites. Consequently, it was reasonable that the compound $\mathbf{S}_{\mathbf{1}}$ showed a high selectivity for cyanide ion [24]. The proposed binding mode of the sensor with $\mathrm{CN}^{-}$in DMSO was shown in Fig. 2. The selectivity of a chemosensors for an anionic species is related to its differential ability to interact with the receptor site in the chemosensor, for instance, through intermolecular hydrogen-bonding [25].

This interaction produces fluorescent complex compounds. The interaction between receptor and $\mathrm{CN}^{-}$anion occured via hydrogen bonding between the hydrogen atoms on the $\mathrm{OH}$ cluster (anion binding site) of the receptor with $\mathrm{CN}^{-}$anion. This interaction produces electron delocalization in fluorescens unit so that the receptor becomes fluorescence. At a concentration of $1 \times 10^{-7} \mathrm{M}$ sensor molecule absorbs at $\lambda_{\text {ex }} 305 \mathrm{~nm}$ and emits light at $\lambda_{\mathrm{em}} 358 \mathrm{~nm}$ with a maximum intensity: 121303 . The addition $5 \times 10^{-6} \mathrm{M}$ of ion $\mathrm{CN}^{-}$causes the absorption $\lambda_{\mathrm{ex}} 320 \mathrm{~nm}$ and emission of light on $\lambda_{\mathrm{em}} 360$ nm with a maximum intensity: 1.09794 (Fig. 3).
For further understanding about the sensing property of $\mathbf{S}_{1}$ to $\mathrm{CN}^{-}$, fluorescent titration experiment was conducted on gradual increase the added $\mathrm{CN}^{-}$concentrations towards the changes of fluorescent intensity. The highest intensity occurred in the addition of $50 \mu \mathrm{L}$ of 50 equivalent ion. At concentrations of 900 and 1000 equivalent ion indicated the highest intensity of 720812 (1000 eq. $\left.1 \times 10^{-1} \mathrm{M}\right)$ [Fig. 3(a) and 3(c)].

The formation analysis of sensor-anion complex $\mathbf{S}_{\mathbf{1}}$ compounds by $\mathrm{CN}^{-}$ion is derived from the the Job's plot (Fig. 4) [26]. The Job's plot for compexation of sensor with $\mathrm{CN}^{-}$ion showed a maximum titration occured in mol fraction ratio of 0.5 by fluorescence spectra. It showed one-to-one binding between $\mathbf{S}_{\mathbf{1}}$ with ion $\mathrm{CN}^{-}$[11] and indicates the formation of receptor-anion complex with a stoichiometric ratio of $1: 1$ [26].

The strength of the formation of sensor-analyte complex can be expressed in the form of $\mathrm{K}_{\text {binding. The value of } \mathrm{K}_{\text {binding }}}$ obtained using quadratic non-linear calculations based on data from fluorescent titration. Fig. 5 shows the plot between the concentration of ions with fluorescent Intensity maximum and the non-linier of calibration curve (insert).

From Fig. 5, the value of $K_{\text {binding }}$ is found to be 2.5 ( \pm 0.26$)$ $\times 10^{6} \mathbf{M}^{-1}$. Compound $\mathbf{S}_{\mathbf{1}}$ is a simpler sensor, it has only one polycyclic aromatic system based on benzimidazole group and has a hydroxyl group as a binding site, which could detect $\mathrm{CN}^{-}$ion at concentration of $\mathbf{S}_{1}$ is $0.1 \mu \mathrm{M}$ producing LOD value (obtained from the calculation [( $3 \times \mathrm{SD}) /$ slope] $)$ is $1.2 \times 10^{-6}$ $\mathrm{M}$ at addition of 50 equivalent ion.

A sensory with two polycyclic aromatics system based on benzimidazol group and naphthalene group, also has one hydroxyl group as a binding site, it has been used to detect $\mathrm{CN}^{-}$ion at concentration of sensor is $20 \mu \mathrm{M}$ producing LOD $8.8 \times 10^{-8} \mathrm{M}$ [12]. So, $\mathbf{S}_{1}$ compound is more sensitive because
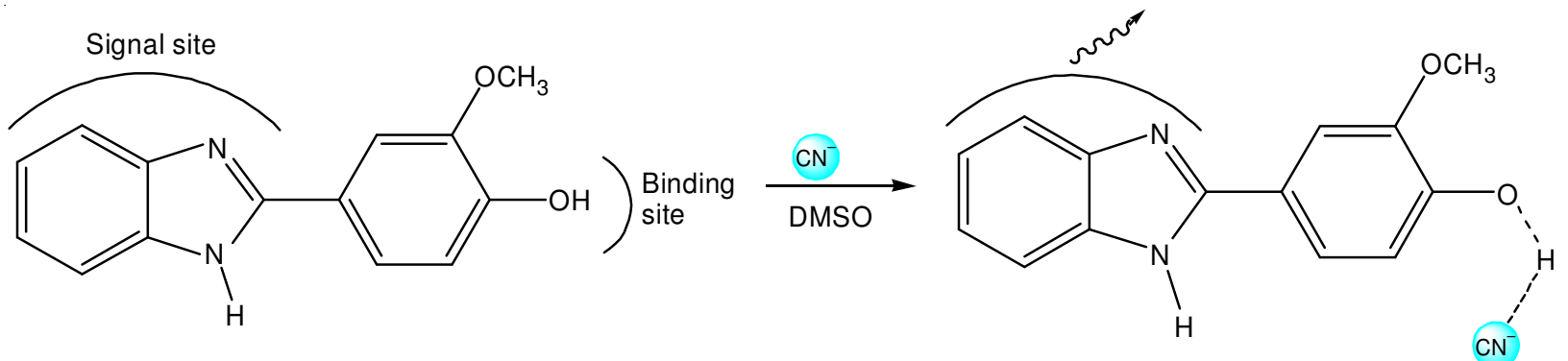

Fig. 2. Possible binding model between compound $\mathbf{S}_{\mathbf{1}}$ and $\mathrm{CN}^{-}$in DMSO
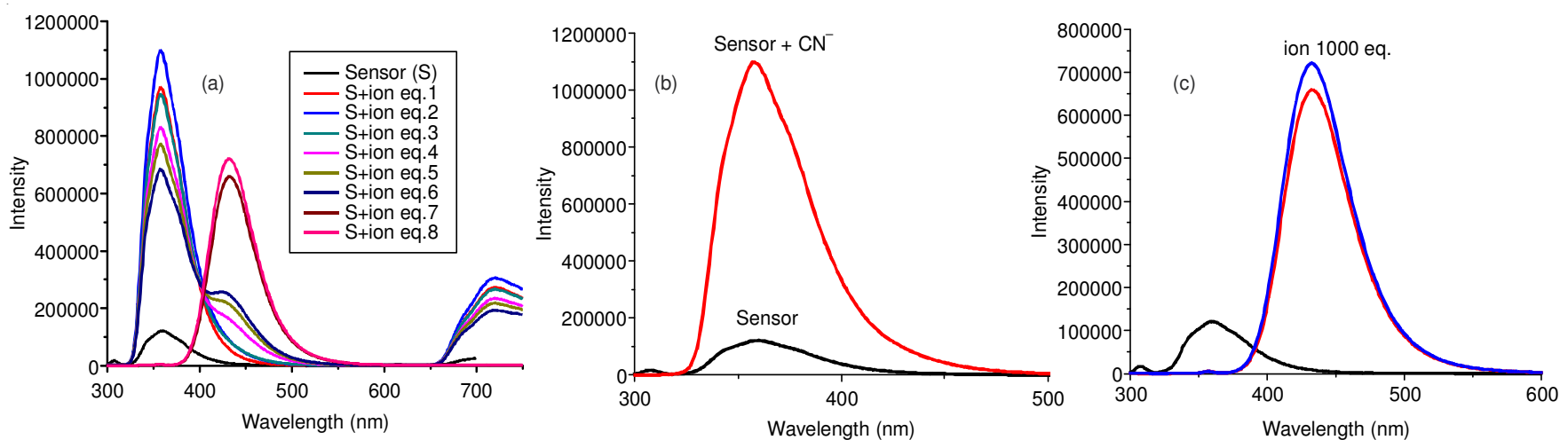

Fig. 3. Fluorescence titration spectra of $\mathbf{S}_{1}\left[10^{-7} \mathrm{M}\right]$ in DMSO solution upon adding of an increasing of $\mathrm{CN}^{-}$(a); titration of $50 \mu \mathrm{L} \mathrm{CN}-50$ eq. $\lambda_{\text {em }} 320 \mathrm{~nm}$ (b); titration of $50 \mu \mathrm{L} \mathrm{CN}^{-} 1000$ eq. $\lambda_{\mathrm{em}} 432 \mathrm{~nm}$ (c) 


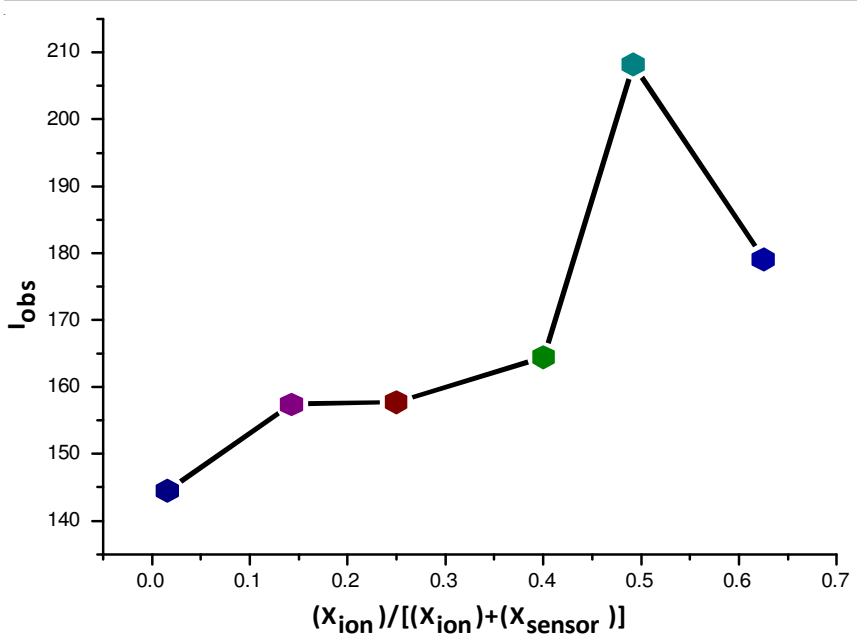

Fig. 4. Job's plot of fracsimole of $\mathrm{CN}^{-}$ion

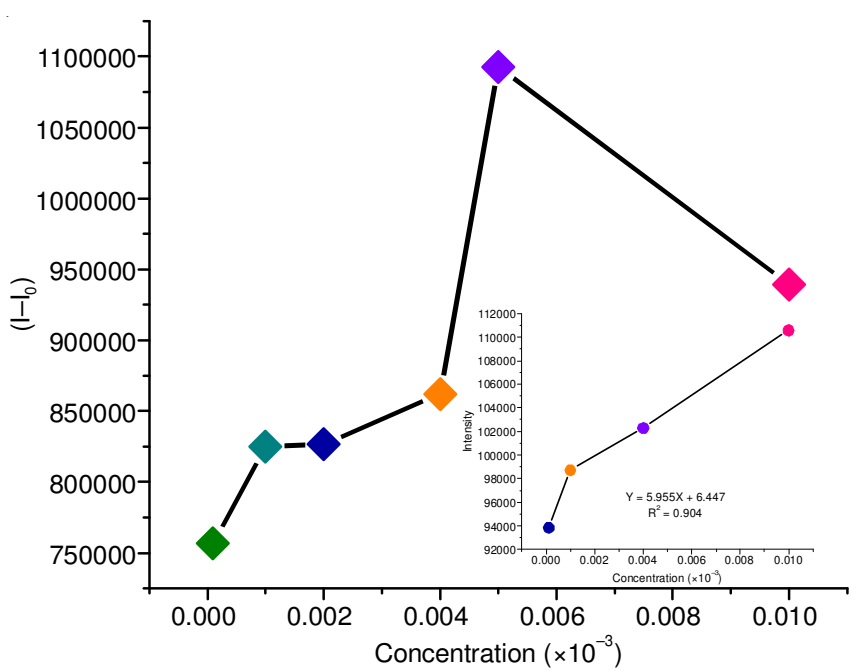

Fig. 5. Plot titrations fluorescence $\mathrm{CN}^{-}$ion (in $10^{-3} \mathrm{M}$ value); (insert) nonlinear calibration curve of titration $\mathrm{CN}^{-}$ion

it can detect $\mathrm{CN}^{-}$ion at lower concentration than WHO standard at lower concentration of sensor.

\section{Conclusion}

A new compound as fluorescence chemosensor for anion were synthesized and studied by spectrofluorometry spectra. Chemosensor 4-(1H-benzimidazol-2-yl)-2-methoxy-phenol showed specially highly sensitivity fluorescence recognition (in $1 \times 10^{-7} \mathrm{M}$ ) for $\mathrm{CN}^{-}$in DMSO solution. The sensor demonstrates the detection limit on fluorescence respons of the sensor to $\mathrm{CN}^{-}$is $1.2 \times 10^{-6} \mathrm{M}$, which is lower than the $\mathrm{WHO}$ guideline [12] of $1.9 \times 10^{-6} \mathrm{M}$.

\section{ACKNOWLEDGEMENTS}

The authors are grateful for financial grant from Penelitian Unggulan Perguruan Tinggi (PUPT), Universitas Gadjah Mada with contract number 918/UN-P.III/CT/Dit-Lit/2016; dated March $1^{\text {st }} 2016$.

\section{REFERENCES}

1. H. Khanmohammadi, K. Rezaeian and A. Abdollahi, Spectrochim. Acta A, 139, 405 (2015); https://doi.org/10.1016/j.saa.2014.12.088

2. X. Shang, Y. Wang, X. Wei, Z. Fu, J. Zhang and X. Xu, Molecules, 18, 14840 (2013); https://doi.org/10.3390/molecules 181214840 .

3. N. Dikshit, M. Tiwari and A. Dewan, Natl. J. Med. Res., 4, 106 (2014).

4. G.J. Park, I.H. Hwang, E.J. Song, H. Kim and C. Kim, Tetrahedron, 70, 2822 (2014); https://doi.org/10.1016/j.tet.2014.02.055.

5. R.M.F. Batista, R.C.M. Ferreira, M.M.M. Raposo and S.P.G. Costa, Tetrahedron, 68, 7322 (2012);

https://doi.org/10.1016/j.tet.2012.06.087.

6. Z. Karimi-Jaberi and M. Amiri, E-J. Chem., 9, 167 (2012); https://doi.org/10.1155/2012/793978.

7. X. Bao and Y. Zhou, Sens. Actuators B Chem., 147, 434 (2010); https://doi.org/10.1016/j.snb.2010.03.068.

8. G.J. Park, Y.W. Choi, D. Lee and C. Kim, Spectrochim. Acta A, 132, 771 (2014);

https://doi.org/10.1016/j.saa.2014.06.001.

9. O. Çimen, H. Dinçalp and C. Varlikli, Sens. Actuators B Chem., 209, 853 (2015); https://doi.org/10.1016/j.snb.2014.12.056.

10. L. Chen, H. Nie, G. Zhang, F. Gong, Y. Yang, C. Gong, Q. Tang and K. Xiao, Tetrahedron Lett., 55, 3017 (2014); https://doi.org/10.1016/j.tetlet.2014.03.097.

11. S.-Y. Na and H.-J. Kim, Tetrahedron Lett., 56, 493 (2015); https://doi.org/10.1016/j.tetlet.2014.12.083.

12. J.-B. Li, J.-H. Hu, J.-J. Chen and J. Qi, Spectrochim. Acta A, 133, 773 (2014); https://doi.org/10.1016/j.saa.2014.06.060

13. Y. Zhang, B. Zou, Z. Chen, Y. Pan, H. Wang, H. Liang and X. Yi, Bioorg. Med. Chem. Lett., 21, 6811 (2011); https://doi.org/10.1016/j.bmcl.2011.09.029.

14. N. Kaur, G. Dhaka and J. Singh, Tetrahedron Lett., 56, 1162 (2015); https://doi.org/10.1016/i.tetlet.2015.01.128.

15. A.S. Gupta, K. Paul and V. Luxami, Inorg. Chim. Acta, 443, 57 (2016); https://doi.org/10.1016/j.ica.2015.11.024.

16. W. Zheng, X. He, H. Chen, Y. Gao and H. Li, Spectrochim. Acta A, 124, 97 (2014); https://doi.org/10.1016/j.saa.2013.12.098.

17. Y.-C. Wang, L.-Z. Liu, Y.-M. Pan and H.-S. Wang, Molecules, 16, 100 (2010); https://doi.org/10.3390/molecules 16010100.

18. L. Jun, L. Qi, Y.M. Zhang and T.B. Wei, Sci. China Chem., 57, 1257 (2014); https://doi.org/10.1007/s11426-014-5108-9.

19. T.B. Nguyen, J.L. Bescont, L. Ermolenko and A. Al-Mourabit, Org. Lett., 15, 6218 (2013); https://doi.org/10.1021/ol403064z.

20. Y. Kim, M.R. Kumar, N. Park, Y. Heo and S. Lee, J. Org. Chem., 76, 9577 (2011); https://doi.org/10.1021/jo2019416.

21. M. Rekha, A. Hamza, B.R. Venugopal and N. Nagaraju, Chin. J. Catal., 33, 439 (2012); https://doi.org/10.1016/S1872-2067(11)60338-0.

22. W. Cui, R.B. Kargbo, Z. Sajjadi-Hashemi, F. Ahmed and J.F. Gauuan, Synlett, 247 (2012); https://doi.org/10.1055/s-0031-1290129.

23. V. Reena, S. Suganya and S. Velmathi, J. Fluor. Chem., 153, 89 (2013); https://doi.org/10.1016/i.jfluchem.2013.05.010.

24. J. Shao, Dyes Pigments, 87, 272 (2010); https://doi.org/10.1016/j.dyepig.2010.04.007.

25. C.R. Nicoleti, V.G. Marini, L.M. Zimmermann and V.G. Machado, J. Braz. Chem. Soc., 23, 1488 (2012); https://doi.org/10.1590/S0103-50532012005000007.

26. H. Su, H. Lin, Z. Cai and H. Lin, J. Incl. Phenom. Macrocycl. Chem., 67, 183 (2010); https://doi.org/10.1007/s10847-009-9695-6 